\title{
Cuts and Simplifications
}

As is already evident, the versions of Jane Austen in Norwegian are different from the English original. Inevitably, a translated text will always differ from the source text. This has to do with the impossibility of achieving a word-forword equivalence between two languages, but also the fact that a translation is put to different uses at different times and places. As Susan Bassnett says:

What happens in translation is that a text is reconfigured in accordance with the demands of the target culture, and there are occasions when that reconfiguration conceals or distorts the values of the source text or culture so as to meet the expectations of the target culture. ${ }^{1}$

Lawrence Venuti uses even stronger phrases in often calling translation practice "imperialistic impulse" or "ethnocentric violence". 2 A translation will always violate the source and adopt it for its own purposes. So, there is nothing remarkable in noting changes and shifts in translated literature. What is of great interest, though, is observing which shifts take place and for what ends. This requires a close reading of translations: “...by studying translation it becomes possible to see how a text is manipulated and changed as it crosses linguistic boundaries, with the translator just one of the agents involved in textual production and distribution". ${ }^{3}$

Jane Austen's novels are changed into their Norwegian versions by artists designing covers, by publishers commissioning translations and series of them, by the editors that select translators for the job. They all turn out to be decisive factors in her reception, forming the Norwegian image of the author.

The translators are major agents whose stamp will always be clearly visible in the translation, even when they remain anonymous, like the 1871 one in

1 Bassnett, Translation Studies, 86.

2 "[T] he imperialistic impulse that may well be indissociable from translation" (Venuti, Translation Studies Reader, 20); "the ethnocentric violence that every act of translation wreaks on a foreign text" (Venuti, The Translator's Invisibility, 121). This violence, he finds, can only be matched by a "foreignizing" strategy, see Chapter 9 below.

3 The quotation describes the fruits of the "cultural turn" in translation theory in the 199os (Bassnett, Translation Studies, 86).

(C) MARIE NEDREGOTTEN SøRBø, 2018 | DOI 10.1163/9789004337176_004 
Norway. ${ }^{4}$ Their identity in such cases may be unknown, but, nevertheless, their language style as well as aesthetic and ethical preferences become familiar.

Although translation always involves change, some translations are more drastically changed than other versions of the same source text. Particularly in past periods, there are often radical alterations to fit the new cultural context. This impulse to amend the original work is perhaps the hybris of the translator (or conceivably the publisher). Such efforts range from minor adjustments to suit a new period and readership, a removal of what is perceived as outdated or unsuitable, a change of style to one that seems more appropriate, or at the other end of the scale, extensive deletions and rewritings.

None of our seven translators (and their publishers) is free of such impulses, but while two or three of them have an evident reverence for their author, the others succumb to temptation. Their submission takes two major directions: cuts and simplifications on the one hand, and additions and elaborations on the other.

Of the six translations under consideration here, four give us a considerably abbreviated novel. Their motives for doing so seem to vary, and one motive the desire to censor certain aspects of Austen's work - will be dealt with in Chapter 11 below. The other deletions tend to be less ideological and more pragmatic. A closer look at some of them will serve to illustrate the issue, which has proved to be involved not only in Norwegian reception. Works may not often be as heavily reduced as the two first Austen novels in French, which retained only one third of the original text, but considerable reduction has still been common practice until recent times. ${ }^{5}$

\section{Missing Snippets of Irony in 1871}

The only nineteenth-century Norwegian translator of Austen preserved much more of her text than most of those of the twentieth-century. There are few deletions in this version of Persuasion, although occasional phrases and sentences have gone missing. Mostly the translator keeps all details, even of apparently minor matters. There are, however, a few striking exceptions to this rule, one of them the treatment of the final chapter. Even if this is for the most

4 When Lawrence Venuti writes of the "invisibility" of the translator, he is lamenting their low status and unrecognized role, not describing their effect on their translations.

5 Cossy, Valerie and Diego Saglia, "Translations", in Jane Austen in Context, ed. Janet Todd, Cambridge, 2007, 169-81. 
part painstakingly accurate, the beginning and end are substantially modified, affecting its ironic purport (see below, Chapter 10: Irony).

The first significant cut, however, appears already in the first page of the newspaper serial. When observing that the widowed Lady Russell has not re-entered the marriage market, the narrator's ironic aside has been deleted: "the public ... is rather apt to be unreasonably discontented when a woman does marry again, than when she does not". ${ }^{6}$

The omission may be down to a dislike for narrative commentary, rather than for ironic humour on female roles. Another paragraph of narrative philosophizing is dropped from I, 8, about the temptation to ridicule overweight and over-sentimentality, especially when combined in the figure of Mrs Musgrove sighing over her son: ${ }^{7}$

Personal size and mental sorrow have certainly no necessary proportions. A large bulky figure has as good a right to be in deep affliction, as the most graceful set of limbs in the world. But, fair or not fair, there are unbecoming conjunctions, which reason will patronize in vain, - which taste cannot tolerate, - which ridicule will seize. (68)

This translator does, indeed, not seize the opportunity for such unseemly ridicule, but again, it is probably down to commentary being unwanted, rather than the nature of the comment itself. In a later chapter, his scissors snip off Anne's reflections on deceitful characters, that Mrs Clay is "bad enough" and Mr Elliot "a deeper hypocrite" (215). ${ }^{8}$ These are however exceptions to the standard strategy of preservation which dominates this early translation.

\section{Minor Surgery in 1930}

Judging from his preface, Alf Harbitz sees himself as not only translator, but also editor of the text. As the novel is so old, he feels the need to "speed up" and "retune" it for modern Norwegian readers. ${ }^{9}$ It is this increased speed, or pace, that seems to be the object behind many of his cuts. Although the cuts are mostly cleverly done, and the essence of the passage often preserved, he

6 Jane Austen, Northanger Abbey and Persuasion, ed. R.W. Chapman, Oxford, third edn, 1983, 5 (all references are to this edition of the novel).

7 Austen, Familien Elliot, 28 December 1871.

8 Ibid., 17 January 1872.

9 "Med stor varsomhet er tempoet satt op ... å stemme boken om" (Harbitz, "Preface", 3-4). 
risks losing important points. When Mrs Bennet reveals her immature character in her effusions about officers, Harbitz misses the point when he cuts her declaration that she still likes them. This is the ironic contradiction of her starting-point: that she and Mr Bennet are sensible adults that do not think of officers (I, 7) ${ }^{10}$ In the same place Mr Bennet's starkly ironic statement that he had hoped the two of them agreed on all points is cut and he just says matterof-factly: "On this point we do not entirely agree".11

Harbitz can serve as an example that even a good translator with a decent mastery of both languages will lose more than he must have foreseen when performing what he would regard as minor surgery on the body of the novel. The examples above and below demonstrate that even small cuts - let alone the more drastic amputations - will often result in a loss of points, a loss of key concepts and famous lines, a loss of connection (for instance prolepsis) and the loss of humour and style, in addition to the major loss of irony that will be further considered in Chapter 10.

As for loss of key concepts, we need only look at the striking omission made in I, 8, where he has discarded all of Elizabeth's contribution to the argument about "the accomplished woman", briefly dismissing the episode with the summary: "There ensued a whole discussion on what young ladies should know". ${ }^{12}$ It is no longer an argument, in fact, since Elizabeth's objections are gone, but only a statement of what young ladies should learn to do, as listed by Miss Bingley and Mr Darcy. The point made is thus the opposite of Austen's. And the key concept of accomplishments has vanished altogether.

Another small cut costs him the famous line about Elizabeth polluting the "shades of Pemberley" (357). Here, Lady Catherine only says, "Heaven and earth! of what are you thinking?" while the next sentence - "Are the shades of Pemberley to be thus polluted?" - is deleted..$^{13}$

Harbitz very often cuts small bits here and there, in fact too many to make a note of, and frequently leaves a reader puzzled as to the purpose of the cuts. A case in point is Mrs Bennet's evaluation of Lady Catherine: "It is a pity that great ladies in general are not more like her" (67), which serves as proleptic, dramatic irony (the readers will soon come to see that it is a blessing that not

\footnotetext{
$10 \quad$ Jane Austen, Pride and Prejudice, ed. R.W. Chapman, Oxford, third edn, 1983. All references to the novel will be to this edition.

11 "I dette punkt er vi nok ikke helt enige" (Austen, Elizabeth og hennes søstre, 28).

12 "Der blev en hel diskusjon om hvad unge damer må kunne" (ibid., 34).

13 "Himmel og jord - hvad er det De tenker på?" (ibid., 231).
} 
more great ladies are like her), but which he probably only sees as another unnecessary polite phrase. ${ }^{14}$

In I, 10 Harbitz cuts a whole page of the discussion between Darcy, Elizabeth and Bingley - a discussion that demonstrates the difference of character and a hint of tension between the two friends. He has kept enough of it to give an idea of this. What he does lose, however, is the proleptic significance of this discussion of whether Bingley should listen to his friend's advice or act on his own impulses. Bingley is accused of yielding too easily to the persuasion of friends. The irony of this is that it is Darcy who condemns this quality in Bingley, but who later is the one to influence him to drop Jane. While Elizabeth is the one to admire his persuasiveness here, later she will see the unfortunate consequences for her sister, and accuse Darcy bitterly for having acted on it. In addition, in cutting this page, Harbitz also loses an example of the early fencing between Elizabeth and Darcy - a verbal fight that threatens to become a quarrel and is therefore called off by Bingley.

Not very much is gained in space through these small cuts (if this is an object), but he loses the small hints, the ironic twists, the unexpected perspective. There must be an underlying idea that Austen is too wordy, long-winded, and that some pruning will do her good and polish her up for new readers.

Once a translator starts cutting, it is difficult to avoid losing connections. Quite often we find that phrases point back to what has just been cut. When Elizabeth asks Wickham: "Can such abominable pride as his, have ever done him good?" ( 81$)^{15}$ - the question seems unmotivated, and something she would not even have considered, if not for the fact that it is Wickham who, in the original, has just indicated that "pride ... has connected him nearer with virtue than any other feeling" (81). When this is cut, as it is in Harbitz, Elizabeth's question seems rather odd. ${ }^{16}$

Harbitz appears to act on the principle that simplification is an improvement, and therefore generally abbreviates. His version is readable and enjoyable, but compared to the original the losses are striking. Sometimes he loses only a few, but significant words, as in Elizabeth's first reaction to Darcy's proposal: "Elizabeth's astonishment was beyond expression. She stared, coloured, doubted, and was silent" (189) which is reduced to "Elizabeth stared

14 The same goes for the loss of Collins' words about Miss de Bourgh's poor physique, which effectively contradict his eager assurances that she is a superior lady.

15 "Kan den avskyelige stoltheten hans ha gjort ham noget godt?" (ibid., 64).

16 The same problem is seen when losing a reference to Darcy in some news about Wickham, so that the following "each of them" becomes meaningless ("hver av dem", ibid., 156). 
at him, turned red, but did not answer".17 The reduction is pointless, and there is a real loss of narrative style.

At other times, Harbitz deletes long passages, and loses funny or significant events, but more importantly perhaps, the peculiarities of certain characters. In the long chapter about the Netherfield Ball $(\mathrm{I}, 18)$, he has kept almost everything, except the one-and-a-half pages about Collins introducing himself to Darcy. Does he want to reduce Collins' ridiculousness, and to soften the irony on the clergyman?

In one instance, he omits an entire chapter (II, 16). The lost event is the story of the sisters' journey from London to Longbourn and their reception there. The lost characterization and thematic interest is the portrait of Lydia. Her talkativeness, stupidity and insensitivity fill the chapter. This is highly relevant for what happens to her later. ${ }^{18}$

He surprisingly also cuts lines that form significant steps in the revelation of the main character, such as Elizabeth's view that Wickham is trustworthy because "there was truth in his looks", and that she knew "exactly what to think" about him and Darcy (I, 17). These are phrases that relate to Elizabeth's personality, the formation of her prejudices, and her attraction to Wickham. It is inconceivable that they could be seen as irrelevant.

Alf Harbitz very often cuts final passages from chapters, which sometimes gives the impression that Austen is treated as a journalist that can be cut from the bottom if the article is too long for the allotted space. ${ }^{19}$ When deleting the last paragraph of $\mathrm{I}, 17$, he probably feels that it is just small-talk about rainy weather and impatient girls with silly preoccupations, and yet, readers with access to the original will see it as a taste of Austen's sharp observations and humorous descriptions of people's foibles.

\section{The Random Reductions of 1947}

Lalli Knutsen has not provided us with any preface or indications elsewhere of her views of Austen's authorship or her own translation strategies, but

17 "Elizabeth stirret på ham, blev rød, men svarte ikke" (ibid., 137).

18 Another journey that is cut short is the Derbyshire tour, so that they here go straight to Lambton as their only goal and to Pemberley from there.

19 By cutting and summarizing the end of I, 9, he loses for instance Darcy's unwillingness to criticize Elizabeth. At the end of I, 12 he loses the paragraph about Mary's reading and the younger sisters' gossip about officers. He cuts several pieces of information from the beginning, middle and end of Elizabeth's conversation with Wickham in I, 16, and from III, 2 (Chapter Forty-Three in Harbitz) about Darcy and his sister visiting Elizabeth at Lambton. The examples are not exhaustive. 
her version is also a heavily abbreviated one. She includes more of the novel than Harbitz did seventeen years before, ${ }^{20}$ although again a full chapter is deleted, this time I, ${ }^{12} .^{21}$ She selects a paragraph about Darcy's resolution to avoid Elizabeth, attaches it to the end of the previous chapter, and discards the rest, an ironic description of the plotting and planning at Netherfield and Longbourn. ${ }^{22}$

Like Harbitz, Knutsen has many examples of small cuts with proportionately greater losses. She, inexplicably, takes out the only sentence about Collins' external appearance and age - "a tall, heavy-looking young man of five and twenty" - when arriving at Longbourn, and keeps only his formality $(64) \cdot{ }^{23}$ She cuts the few words about Lady Catherine's suggestion of putting up shelves in the parsonage (66). ${ }^{24}$ After keeping the rest of the passage, this seems pointless. As a result, she loses a prime example of Lady Catherine's interfering nature.

Knutsen generally simplifies sentences by omitting words and phrases here and there. Even at her best - her Chapter $15(\mathrm{I}, 16)$ is almost intact, and in a light and readable tone - she frequently shaves off small bits. Sometimes, the suspicion arises that she does not understand the original, and chooses an easy way out. When she keeps everything that goes before and after, but cuts Lydia's talk about "the fish she had lost and the fish she had won", she probably does not recognize the reference to the party game. Retaining most of Collins' talkativeness but cutting his "repeatedly fearing that he crouded his cousins" in the carriage home, she may have missed the point (84). ${ }^{25}$ At other times, this cannot be the reason, and Knutsen therefore obviously selects and discards as well as translates.

Sometimes the loss is one of logic. When a line disappears from Elizabeth's reflections on her own blindness, it destroys the logic of her reasoning. "Had I

20 For instance, Knutsen's version of the proposal scene (II, 11) compares favourably to Harbitz's. It is probably one of her best chapters, with only a few weaknesses.

21 This is exactly the same chapter that is deleted in Ebba Brusendorff's Danish translation (Jane Austen, Stolthed og fordom, Copenhagen: Gyldendalske, 1928-30). It appears to be more than a coincidence, since Knutsen's sentences sometimes follow her predecessor's fairly closely, and yet, the two versions are not identical. Knutsen makes mistakes that are not found in Brusendorff, and the latter version is a fuller one. Knutsen may have had the Danish translation at hand while she was working, but it was not her only source. We must therefore assume she also worked from Austen's original.

22 Knutsen's version seems at first glance to be two chapters shorter than the original novel (she has 59 chapters in all), but the second is a lost chapter division, rather than lost content.

23 Austen, Stolthet og fordom, Oslo, 1947, 64.

24 Ibid., 66.

25 Ibid., 81. 
been in love, I could not have been more wretchedly blind" is gone in Knutsen, but she keeps the continuation: "But my fault has been vanity, not love", leaving a "but" that has nothing to refer back to (208). ${ }^{26}$

At other times, the loss is one of humour. When she deletes five lines of narrator's comment on Lady Catherine's tendency to answer most of her own questions, she clearly loses one of Austen's jokes (212). ${ }^{27}$ Another is lost when she cuts Elizabeth's teasing comment about "the moral" of their happy ending being poor since it is caused by a breach of promise $(381) .{ }^{28}$ The character here mirrors the author's concern as she is coming to the end of her novel, and her consciousness of having to answer to genre expectations. Knutsen must not have understood the joke.

She also cuts a shorter paragraph that points to Collins' "pompous nothings" and the girls' "civil assents" to them (72). ${ }^{29}$ But Austen's paragraph is certainly not pompous nothings that can be cut without damage. Some translators seem to fall into the trap of thinking that this is just small-talk, which does not help the action, and is therefore dispensable.

One of Knutsen's longer cuts, the last page of her Chapter $14(\mathrm{I}, 15)$, removes the episode in Mrs Phillips' house. She thus discards a prime example of Austen's free indirect style (see page 103 below), a glimpse of Aunt Phillips' contribution to the girls' silly flirtations with officers, and another enjoyable example of Collins' ridiculousness. Even in the part of the episode she does keep, she cuts the sentence about Darcy's attempts not to look at Elizabeth (73), which seems an odd choice, as it is an early link in the chain of events of the main love story. ${ }^{30}$

Knutsen sacrifices more such links in deleting Elizabeth's inner questions, revealing how much she is preoccupied with "what if" thoughts after refusing Darcy (210). ${ }^{31}$ Like Harbitz, she cuts the last paragraph of II, 15 (her Chapter 37), losing Elizabeth's impatience to tell Jane of Darcy's proposal. As a result, both translators open the following chapter alluding to an impatience that that has not been mentioned before.

Furthermore, Knutsen cuts Elizabeth's thoughts of Darcy in the last short paragraph of her Chapter 42 (III, 1), which is odd, as most of the rest of the

\footnotetext{
26 "Men min feil har vært forfengelighet, ikke kjærlighet" (ibid., 182).

27 Ibid., 185.

28 Ibid., 330.

$29 \quad$ Ibid., 71.

$30 \quad$ Ibid., 72.

$31 \quad$ Ibid., 184
} 
chapter is retained. Why end the dramatic Pemberley tour with the lines about Mrs Gardiner's activities rather than the focus on Elizabeth's feelings?

In the same way - and in spite of keeping (but rewriting) the rest - Knutsen cuts three lines in her Chapter 44 (III, 3), namely Darcy's motives for not telling Bingley about Wickham's planned elopement with his sister. More importantly, she cuts a paragraph about Elizabeth's mixed wish and fear that Darcy might appear. Did she find it too complicated to translate? The idea is certainly central to the main plot.

Why does she cut thirteen lines describing Elizabeth's intense regrets at having lost Darcy? ${ }^{32}$ Austen here repeats the phrase "She was/she regretted/she became/she wanted", and similar, no less than eight times over six lines, thus directing a clear focus on Elizabeth's emotions (311). Why would any translator want to cut this from a novel about love overcoming pride and prejudice? It is one of a few such key passages showing us Elizabeth's process of change, her radical turnaround. Harbitz also cuts it, along with the rest of the page, while Knutsen has kept the rest, but cut these lines. ${ }^{33}$

Similarly, Knutsen has reduced Elizabeth's impatience while waiting for Darcy in the drawing-room in III, 12, for instance by deleting her decision to give him up if he does not come to speak to her, and also the "alas!" that reflects her disappointment when he does not come (341). ${ }^{34}$ Readers of Knutsen's version are much less acutely aware of Elizabeth's feelings than readers of Austen's original novel.

For the most part, Knutsen's cuts seem to be random, again often last paragraphs of chapters, as if she has run out of space, or lines in between that she perhaps does not understand, or see the point of. There seems to be no consistent censoring involved, in spite of the noted reduction of Elizabeth's emotions (see Chapter 11: Censoring).

\section{The 1972 Deletions and Substitutions}

Elisabeth and Eivind Hauge translate more of Pride and Prejudice than Knutsen did: so far, each Norwegian version is longer than the previous one.

$32 \quad$ Ibid., 267.

33 All such editing is most likely done by Lalli Knutsen herself. Not only is her Danish predecessor fuller, so is her Swedish one. The 1920 translation by C.A. Ringenson had just had a revised edition in 1946, but he does not have the same deletions as Knutsen (Jane Austen, Stolthet och fördom, Stockholm: Albert Bonniers Förlag, 1920). 
Nevertheless, they do abbreviate substantially, and what is more, they paraphrase and rewrite the novel.

The Hauges sometimes delete longer sections, for instance nearly one third of I, 14, which means that the chapter here ends with Mr Bennet's enjoyment of Mr Collins' absurdity, rather than being tired of him. Another consequence is losing the young Bennet ladies' preference for novel-reading over their clergyman cousin's sermons.

The more common translation method is, however, to cut bits and pieces all over, as if planing the text down. The numerous smaller cuts, which amount to constant trimmings of the original text, lead to a loss of significant moments of the novel. They chisel off Elizabeth feeling "sick of this folly" while listening to her mother $(307) \cdot{ }^{35}$ It is one of the clearest condemnations of superficiality found in the novel.

Although the lost text bits may be short, they will be sorely missed. In their urge to reduce the text, Eivind and Elisabeth Hauge tend to lose the colourful details, the funny particulars of any scene. They omit Elizabeth's nose from Miss Bingley's denigration of the features of her face (271). ${ }^{36}$ They miss the price of Lady Catherine's chimney-piece. ${ }^{37}$ They cut the details of Elizabeth and Jane running from room to room looking for their father, and substitute them with the most meagre summary (301).38 "All particulars of calico, muslin and cambric" are gone from the brief report of Mrs Bennet's wedding-plans (307). ${ }^{39}$ Instead of being served "venison ... roasted to a turn ... a soup ... fifty times better" than the Lucas', and "remarkably well done" partridges, we only have a good dinner (342)..$^{40}$

The main characteristic of the Hauges' method of translation is, however, not mere deletion, but the more radical practice of simplification and summary of narration. Harbitz, Knutsen and the Hauges all share the same tendency to improve Austen by simplifying her language. Still, the Hauges go further than the others in drastic reductions and prosaic summaries of what was once humorous and elegant narration.

35 Austen, Stolthet og fordom, c. 1972, 241.

36 Ibid., 213 .

37 In the opening of $\mathrm{I}, 16$.

38 Austen, Stolthet og fordom, c.1972, 236.

39 Mrs Bennet is merely reported as intending to "plan the trousseau" ("planlegging av utstyr", ibid., 241). The same happens in Knutsen where she is only said to have "listed everything in detail" ("regnet detaljert opp alt", Austen, Stolthet og fordom, 1947, 263). Harbitz cuts the phrase, and only Alfsen (2003) keeps these colourful details.

"Middagen var så god som den kunne være" (Austen, Stolthet og fordom, c. 1972, 270). 
Here is a comment on the ensuing disappointment after having one's wishes fulfilled:

Upon the whole, therefore, she found, what has been sometimes found before, that an event to which she had looked forward with impatient desire, did not in taking place, bring all the satisfaction she had promised herself. It was consequently necessary to name some other period for the commencement of actual felicity; to have some other point on which her wishes and hopes might be fixed, and by again enjoying the pleasure of anticipation, console herself for the present, and prepare for another disappointment. (237)

In the Hauges' version, the whole of this passage is reduced to: "It was therefore good that she herself had something to look forward to". ${ }^{41}$ Evidently, they have no use for narrator's comments and ironic jokes on Elizabeth's moral self-discipline.

A quantitative comparison of the two versions of I, 15 is quite illustrative. An ironic description of Mr Collins making a nuisance of himself in Mr Bennet's library takes up eighteen lines in Austen, and five-and-a-half lines in Hauge. The episode of the visit to Mrs Phillips' house consists of fifty-four lines in Austen, twenty-nine in Hauge. There is thus a high degree of revision and freedom of translation. ${ }^{42}$

A qualitative comparison of the same chapter shows that it mainly consists of rewritings, with phrases that are always flatter and more prosaic than the original: "Miss Bennet's lovely face confirmed his views" becomes "Jane in particular tempted him". ${ }^{43}$ Jane's elegantly described incomprehension: "though Jane would have defended either or both, had they appeared to be wrong, she could no more explain such behaviour than her sister" is merely "Nor could Jane understand it". ${ }^{4}$

The translators lose much of the significance of the words when they paraphrase what they think is the main idea, rather than replicate Austen's wording. There is so much rewriting in the Hauges' version that it constitutes their chosen method. The examples are too numerous to record - they are in

\footnotetext{
41 "Det var derfor godt at hun selv hadde noe å se frem til" (ibid., 191).

42 If we read their version of I, 15 alongside Alfsen's excellent solution (see below), the difference is striking.

43 "Det var særlig Jane som fristet ham", Austen, Stolthet og fordom, c. 1972, 64.

44 "Jane kunne heller ikke forstå det", ibid., 66.
} 
almost every paragraph of the novel, and mostly consist of simplifications and abbreviations. ${ }^{45}$

They have often caught the point of the story, but seem not to consider it also important to capture the language and the style. The general simplification of Austen's elaborate sentences results in a plain, matter-of-fact, and dull style: "She felt all the perverseness of the mischance" (182) becomes "she was sorry for his bad luck".46 "She had not really any dislike to the scheme" (241) is simply translated "yes". ${ }^{47}$ Perhaps the translators feel that this strategy means clarification of a complicated, old text, but they inevitably sacrifice Austen's language in the process.

"Mr Darcy would find him pushy" is, admittedly, the main meaning of "Mr Darcy would consider his addressing him without introduction as an impertinent freedom, rather than a compliment to his aunt" (97) ${ }^{48}$ It is hardly, however, a similar tone of narration, nor the same level of detail. What we get is a kind of Readers' Digest version of Austen. The underlying idea - that it is possible to give the core of a work without its intact body, is as futile here as in other authorships.

It is tempting to borrow Cleanth Brooks' old dismissal of "the heresy of paraphrase", although of a different genre. He objected to the tendency to reduce poems to their paraphrased meaning, and argues for an integrated reading of form and idea, where the two are, indeed, an inseparable structure. ${ }^{49}$ This is exactly the conclusion when studying translations that seem to care only for the content, the events and characters, and disregard Austen's narration. As Susan Bassnett remarks, this has often happened: "many translations of novels in particular have focused on content at the expense of the formal structuring of the text", and judges this to be "completely inadequate. ${ }^{50}$

The Hauges' intended translation strategy might have been a kind of condensation, perhaps seeing themselves as chefs reducing their sauce to the tasty essence when boiling away the excess water. It hardly works that way in any authorship, and in Austen's stories, the narrative style is inextricably bound with her meaning. Paradoxically, Harbitz's shorter 1930 version has a

45 Abbreviated editions of "the great classics" abounded in the mid-century when the Hauges did most of their translations. Their source, however, was a complete edition (see Chapter 1, n. 62 above).

46 "Hun syntes det var leit for ham" (Austen, Stolthet og fordom, c. 1972, 147).

47 "Ja" (ibid., 194).

48 "Mr. Darcy ville synes han var påtrengende" (ibid., 84).

49 Cleanth Brooks, The Well Wrought Urn, Orlando: Harcourt, 1947/1970, 192-214.

5o Bassnett, 2014, 90. 
superior rendering of Austen's tone, and makes for a better read, compared to the Hauges' longer one. Of the early translators of Pride and Prejudice, Harbitz has the best grasp of Jane Austen's style.

A typical specimen of the simplified narration in the 1972 version is the reduction of a seventeen-line account of a walk in the woods of Pemberley with its paths, views and hills, to a two-line, dry summary: "They walked here and there across the estate, but it was too big for them to walk all around it". 51 It seems, indeed, as if Austen's narrative, like Darcy's park, is too big to be handled in full.

\section{The 1974 Cut-and-Paste}

The enticingly titled serial "Detour towards happiness" (Omvei til lykken) provided the readers of the journal Familien with half a year's worth of entertainment, from spring to autumn 1974. Even so, its version of the novel is far from complete. At least fifteen chapters are heavily reduced, and a couple lost altogether. Nearly all chapters have notable simplifications. It is therefore the most reductive translation (except for the 1996 reissue of the same).

What remains is translated according to a similar principle as that of Alf Harbitz in 1930: with understanding, but with a consistent thinning out of the narrative. This slimmed-down novel may retain much of the action and dialogue (although losing significant parts also here), but often loses Austen's narrative tone, the humorous and ironic distance. Nor does it seem to have been an aim to keep her language, so that her rich style of narration becomes something much more utilitarian, where the sentences are there to communicate the facts, not to form an enjoyable piece of reading. Austen's story is wanted; her literary art less so.

In some places the cut-and-paste technique seems to have got out of hand as parts of one chapter are transplanted onto another, leading to the loss of important elements and connections, for instance when passages from I, 21 are grafted onto I, 23 (also in III, 16-17 and 18). Nevertheless, other parts of the novel are quite closely translated, with a decent understanding, and sometimes felicitous renderings.

Some translation scholars would prefer to call such abbreviated serials "adaptations" rather than translations. For several reasons, this is not done here. It is not easy to discriminate between adaptation and translation proper

$5^{1} \quad$ "De spaserte på kryss og tvers av eiendommen, men den var for stor til at de kunne gå helt rundt den" (Austen, Stolthet og fordom, c. 1972, 201). 
when, for instance, both employ abbreviations. Wherever we draw the line, it would be a difference of scale, not of kind. The 1974 translation, like several of the others, alternates between liberal editing and close (sentence by sentence) translation.

Furthermore, it is convenient to have only one category for translations, whatever their strategies and results. Translation can then simply be defined as rendering a text in another language. This simplification of the terminology is in keeping with recent emphasis on hermeneutic approaches to translation. ${ }^{52}$ Susan Bassnett also observes that "Much time and ink has been wasted attempting to differentiate between translations, versions, adaptations and the establishment of a hierarchy of 'correctness' between these categories".53 The hermeneutic emphasis on the reader as interpreter of the text, and the many potential readings of it, makes the sub-categories redundant. Any "deviant" translation is also an individual reader's interpretation, as is, indeed, a "faithful" translation.

\section{3: Darcy's Fruit Slipping between Our Fingers}

Merete Alfsen has a strategy opposite to that of her predecessors: she clearly aims to incorporate all, or most, details of Pride and Prejudice in her translation. Some of the miniscule details of Austen's story, visible only by careful reading, are left out by all previous translators and have never before appeared in print in Norwegian. They include Austen's little dig at feminine accomplishments: "their own indifferent imitations of china on the mantelpiece", or the minor figure of "the broad-faced, stuffy uncle Philips", who is otherwise often forgotten $\left(75^{-76)} \cdot{ }^{54}\right.$

Alfsen is the only translator thorough enough to translate even the seemingly insignificant "Yes, yes" in between Mrs Bennet's sentences (228). ${ }^{55}$ It serves the portrait of Mrs Bennet as an absurd chatterbox, and if translators aim to keep only the main meaning of a passage, they lose such characteristic traits that distinguish one person from another.

$5^{2}$ Routledge Encyclopedia of Translation Studies, eds Mona Baker and G. Saldanha, London and New York, Routledge, 2009, 199.

53 Bassnett, 2014, 90.

54 Austen, Stolthet og fordom, 2003, 77: "studere sine egne middelmådige porselensimitasjoner på kaminhyllen”; “den bredfjesete, oppstyltede og portvinsdunstende onkel Philips”.

55 "Ja da", ibid., 216. 
This does not mean that Alfsen does not occasionally slip up, but not often, and there seem to be few, if any, deliberate cuts. She does lose the odd words and phrases, though. Surprisingly, she deletes the striking condemnation of Mrs Bennet's superficiality in Elizabeth feeling "sick of this folly" (307) ${ }^{56}$ She must have overlooked it, since it is impossible to find it an unnecessary phrase (see pages 183-184 below).

Occasionally, Austen's elaborate style is slightly simplified, as when reducing Elizabeth's three parallel phrases to two: [Lydia] "has left all her friends - has eloped; has thrown herself into the power of - of Mr Wickham" (277). In addition, she drops the hesitant repetition of the word "of" before the name can be pronounced: a hesitation that seems significant, and not random, in Austen. ${ }^{57}$

Whether by chance or choice, Alfsen has also lost Darcy's fruit in III, 3, here a sample of Austen's typical humour. When Elizabeth and her Aunt Gardiner evaluate their Pemberley visit, "They talked of his sister, his friends, his house, his fruit, of every thing but himself" (272). Alfsen keeps the rest but discards the fruit. ${ }^{58}$ The guests were served an impressive and luxurious assortment of fruit, well worth talking about, but the point is their stubborn dwelling on all surrounding details, avoiding the man at the centre of their interest. This point Alfsen has caught, so it is strange that she does not include the fruit, which brings out the humour more than anything else.

Darcy's fruit has disappeared from three of the other translations as well. Harbitz and the 1974 translator have both deleted the relevant paragraphs, and thereby the humour. The Hauges discard the funny list, and rewrite it into the dull sentence: "They talked of everybody, but not of Mr Darcy".59 Only Knutsen has kept the fruit here. ${ }^{60}$ Unfortunately, she drops the exotic varieties of fruit specified earlier, when they eat them. Thus, "grapes, nectarines and peaches" (268) are simply reduced to "fruit", losing some of the taste of the luxurious loveliness that made such an impression on Elizabeth and her Aunt. ${ }^{61}$

Of our six translators, only two do not rely on cuts and simplifications, namely the oldest (1871) and the most recent one (2003). Although they both

\footnotetext{
$56 \quad$ Ibid., 282.

57 Alfsen has kept only the two first: "har forlatt alle sine venner - har rømt - med mr. Wickham" (ibid., 255-56).

$5^{8}$ "De snakket om søsteren hans, vennene hans, huset hans - om alt annet enn ham selv" (ibid., 251).

59 "De snakket om alle, bare ikke om Mr. Darcy" (Austen, Stolthet og fordom, c. 1972, 214).

6o Austen, Stolthet og fordom, 1947, 233.

61 "frukt" (ibid., 230).
} 
lose some smaller bits and pieces, they evidently aimed to keep the text of the novel virtually intact in their target language. The others resort to extensive simplifications. Sentences and paragraphs are often shortened and rewritten, so that while events and dialogues may still be retained, much of the humour and irony is sacrificed. Reading these translations, they give the impression that Austen is seen as too verbose and that she must be pruned, polished and updated for a new age. 